\title{
EGÉSZSÉGFEJLESZTÉS ÉS NEVELÉS
}

Az MTA Orvosi Tudományok Osztálya a történelmivé rögzülő koronavírus pandémia előtti utolsó osztályülésének végén egyebek közt felmerült, hogy az osztálynak kellene tenni valamit azért, hogy az iskolai nevelés végre kellő súllyal kezelje az egészség, az egészségnevelés oktatását. A kevés izgalmakat hozó napirendi pontok után váratlanul élénk vita vette kezdetét. A felvetést a megszólalók mindegyike lelkesen támogatta, az indokok sorolása mellett a tanrendbe illesztés, a tanrenden kívüli iskolai nevelés különböző formáira, a gyerekek megszólításának iskolán kívüli formáira, multimédiás eszközökre tett különféle javaslatok áradatát végül is azzal sikerült megszakítani, hogy a felmerült akciótervet az osztály napirenden tartja. A heves reakció nem hagyott kétséget afelől, hogy az orvostudományi kutatás alapszabályban, küldetésnyilatkozatban lefektetett, akadémiai szinten történő szervezésén, elősegítésén túl az Orvosi Tudományok Osztályának tagjai kiemelt fontosságot tulajdonítanak a következő generációk egészségtudatos társadalmi magatartásra nevelésének.

Az osztályülést követő héten jutott el hozzám a Feith Helga Judit és Falus András által szerkesztett Egészségfejlesztés és nevelés címü könyv. Az Akadémiai Kiadó által megjelentetett könyv alcíme (A kortársoktatás pedagógiai módszertana elméletben és gyakorlatban) félreérthetetlenül utal arra, hogy egy olyan kiadványt tartok a kezemben, ami szinte közvetlen választ kínál a fent említett élénk eszmecsere során felmerült kérdésekre.

Az MTA Tantárgy-pedagógiai Kutatási Program támogatásával megvalósult könyv harmincnyolc szerző összesen huszonnyolc rövid, pár oldalas munkáját tartalmazza. A szerzők magasan kvalifikált kutatók, egyetemi (nagyrészt Semmelweis Egyetem) oktatók, pedagógusok, egészségügyi-nevelési közigazgatásban tevékenykedők, sőt hallgatói státuszban lévők, akik aktív közremüködők az egészségfejlesztés oktatásának szervezésében, a közvetlen kontakt megvalósításában.

A könyv három fejezetre tagolódik. Az első (Az egészségtudatosság fejlesztése) általános kérdésekkel foglalkozik, így az egészség társadalmi jelentőségével, gazdasági, jogi meghatározóival, az egészséget meghatározó biológiai és társadalmi tényezőkkel, a neveléstudomány és egészségfejlesztés kapcsolatával, az egészségismeretek széles körének készséggé való átadásával. A fejezet bemutatja a neveléstudomány szerepét a komplex, több tudomány bevonását igénylő egészségfejlesztő munkába, értelmezi az egészségfejlesztéssel kapcsolatos fogalmakat, az iskolai egészségfejlesztés lehetséges módjait. Meggyőző érvek kerülnek ismertetésre arra vonatkozóan, hogy az egészségtudatosság társadalmi elfogadtatása je- 
lentős mértékben függ a korszerü orvosbiológiai és pszicho-szociális tudás széles körü hozzáférhetőségétől, az ismeretek átadását végzők személyes motivációjától, az átadás formájától, amelyben az élményszerü, szerethető tudásátadás központi szerepet tölt be. Ebben a fejezetben kerül bemutatásra a 2012-ben életre hívott EDUVITAL Nonprofit Egészségnevelés Társaság (EDUVITAL NET), ami nagyrészt Falus András lelkesítő, meggyőző karakterének, valamint Kopp Mária motivációs hatásának köszönheti létrejöttét. Célja, hogy különféle diszciplínák szakértőinek bevonásával, élményszerủ elemekkel jól használható, felelősségteljes információkat adjon a gyakorlati egészségnevelési munkához, tanácsadáshoz.

A második fejezet $A$ kortársoktatással, az oktatás hatékonyságát jelentős mértékben befolyásoló ismert, de a kelleténél kisebb hangsúlyt kapó tényezőjével foglalkozik, ennek lényegi elemzésén túl a hazánkban több helyen kezdeményezett formák bemutatásával. A kisgyermekek egészséggel összefüggő viselkedésmintáinak kialakítása jó esetben már a családban elkezdődik. A serdülők azonban már leginkább egymásban bíznak, és a barátok társas támogatási szintje meghaladja a szülőkét. Ezért van nagy jelentősége annak, hogy az iskolai programok esetében az egészséges életvitel kialakítását célzó programok megvalósításához segítségül hívjuk a képzett kortársoktatókat. A fejezetben több példát olvashatunk arról, hogy milyen formában történik az egészségprogramok megvalósítása az intézmények igényeihez, lehetőségeihez alkalmazkodva, hogyan vesznek részt a képzésben óvodai foglalkozások, iskolai tanórák keretei között, pedagógus felügyelete mellett az előzetes tréningen átesett kortársoktatók. A kiadványban olvashatunk az EDUVITAL által 2015-ben létrehozott Tanulj, Tanítsd, Tudd (TANTUdSZ) Ifjúsági Egészségnevelő Program szerinti kortársoktatási gyakorlatról, amelynek során az egyes témák feldolgozása interaktív órákon történik a diákok tudására és tapasztalataira építve, élményközpontú kreatív játékokkal, feladatokkal, „kísérletekkel” az alábbi csoportosításban: 1) elsősegélynyújtás, újraélesztés, 2) folyadékfogyasztás, 3) kézhigiéné, 4) internetbiztonság.

A harmadik a kiadvány legegyedibb fejezete, az Egészségprogram receptgyüjtemény. A könyvnek ez a második felét kitevő, 180 oldalnyi rész valódi, a kortársoktató egyetemisták és középiskolások által alkalmazott, kidolgozott receptgyüjteményből áll. A mintegy 160 (!) program mindegyike külön oldalon található azonos sablon szerinti szerkezetben, amelynek állandó elemei a következők: a tevékenység célja; a célcsoport életkora, maximális létszáma; az eszközigény; a játék, kísérlet időigénye; a kortársoktatók életkora, szükséges létszáma; az oktatók előzetes tudásszükséglete, speciális tulajdonságai; a játék, kísérlet stb. pontos és érthető leírása; pedagógiai módszerek, tanulási forma, a célcsoport tudás-, készség-, képességfejlesztésének megnevezése. A receptek szerkesztésének ez a módja jól kiemeli a gyakorlati megvalósítás megszervezéséhez szükséges feltételeket. A „módszertan-tár” szerkesztésénél a fő rendezési elv az életkor. A programelemek óvodás - óvodás/kisiskolás - kisiskolás - kis- 
iskolás/felső tagozatos - felső tagozatos/középiskolás - középiskola/felnőttoktatás szerint tagozódnak. Az egyes életkorokban más-más, korosztály-specifikus témák feldolgozása valósítható meg. Könnyen kezelhetővé teszi a receptgyűjiteményt, hogy a könyvben az egyes témák hovatartozását (1. elsősegélynyújtás/ újraélesztés, 2. folyadékfogyasztás, 3. kézhigiéné, 4. internetbiztonság) a receptek első sorában a négyféle piktogram egyike jelzi. A fejezet tanácsokat is nyújt, hogy mire kell figyelni az egyes programok megvalósítása során.

Most, amikor forgatom ezt a kitűnő kiadványt, a koronavírus-pandémia reflektorfényében különösen élénken rajzolódik ki e recenzió első szakaszában említett igény, nevezetesen a gyerekek egészségtudatos nevelésének fontosága. A kézmosással kapcsolatos készségfejlesztő program szinte azonnal jogot tarthatna éles bevetésre; az egészségtudatos nevelés eredménye adott esetben életmentő jelentőségű lehet. De a könyv értékeit egyéb vonatkozásokban is markánsan aláhúzza a jelen helyzet. A digitális távoktatásra való átállás hajnalán reménykeltő meggyőződéssel mondható, hogy az egészségprogram receptgyüjtemény alkalmasnak látszik arra, hogy a százhatvan program túlnyomó többsége nem túl nagy igazítással eredményesen használható lehet az egészségtudatos életvitel internetalapú, multimédiás, a következő generációk kommunikációs nyelvén történő oktatásra.

Nem nehéz megjósolni, hogy az Egészségfejlesztés és nevelés című úttörő jelentőségű könyv nélkülözhetetlen segédeszköze lesz gyerekeink, unokáink, a következő generációk nevelésének.

(Falus András - Feith Helga Judit: Egészségfejlesztés és nevelés. A kortársoktatás pedagógiai módszertana elméletben és gyakorlatban. Budapest: Akadémiai Kiadó, 2019, 368 o.)

Kosztolányi György gyermekgyógyász, egyetemi tanár 